\title{
河口港における河川濁水の流入と堆積過程に関 する検討
}

\author{
中川康之 1 - 高嶋紀子 2 -村上和男 3 - 後藤嘉雄 4 - 長井一平 5 \\ 1正会員 国立研究開発法人 海洋・港湾・航空技術研究所港湾空港技術研究所沿岸土砂管理研究グループ \\ （干239-0826 神奈川県横須賀市長瀬3丁目1-1） \\ E-mail:nakagawa@pari.go.jp
}

2非会員 国土交通省九州地方整備局 博多港湾 - 空港整備事務所 第三工務課 ( $\bar{T} 810-0074$ 福岡県福岡市中 央区大手門2丁目5-33)

(前 港湾空港技術研究所 沿岸土砂管理研究チーム)

3フェロー会員 東京都市大学名誉教授

( 个158-8557 東京都世田谷区玉堤1-28-1)

4非会員 環境省水・大気環境局 水環境課 (

(前 国土交通省 北陸地方整備局 新潟港湾・空港整備事務所企画調整課 課長)

5 非会員 国土交通省 北陸地方整備局 新潟港湾・空港整備事務所 企画調整課 係長

( ( 950-0954 新潟県新潟市中央区美咲町1丁目1-1)

\begin{abstract}
本研究は河口港湾における浚渫土砂量の軽減策の検討に向けて, 河川上流からの土砂供給や塩水くさび 等の水理条件を考慮した, 河口域特有の土砂動態のメカニズムの理解を目的とする. 現地での底質・水質 調查を通じて明らかとなっている, 河川出水時における河口港湾の浚渫域での塩分および濁度の躍層形成 や, 浚渫による水深急変部におけるFluid mudの集積現象について循環水槽を用いた再現実験を行い, 河川 供給土砂の港湾浚渫域での輸送過程の解明について検討した。これにより, 上流部での濁水漂度の条件に 依存して, 床面上を重力流的に流下寸るFluid mud輸送が発生することを明らかとし, また塩分躍層の有無 が流下する浮遊懸潈物の輸送に影響を及ぼすことを示した。
\end{abstract}

Key Words : river mouth, pycnocline, fluid mud, dredging, Port of Niigata, hydraulic experiment

\section{1.はじめに}

河口港湾では，河川による陸域から供給される土砂の 堆積が生じるため, 航路・泊地の水深維持を目的とした 定期的な浚渫が必要となる場合が多い，近年では，浚渫 土砂の処分場の確保が困難であり，これまで以上に浚渫 量の軽減を含めた効率的な航路・泊地の維持管理が要求 される. 効果的な埋没対策を講じるうえでは, 出水時に おける河川からの土砂供給や港内での堆積過程など, 港 の埋没に関与する主要なプロセスを的確に把握しておく ことが重要である.

このような背景をふまえ，著者らは新潟港西港地区 （信濃川河口）における定期測量結果や，底質・水質調 查等の現地観測データの解析を通じて, 出水前後におけ る地形変化や, 堆積土砂の底質粒径の変化の特徴を明ら かとしてきた ${ }^{11}$ ，その中で，特に出水期間中に行われた 濁度等の空間分布の測定結果により, 河口浚渫域での塩 水・海水による密度界面の形成と連動した浮遊土砂の輸
送や，Fluid mud輸送による航路への土砂侵入を示唆する 底面での高含水比底泥の集積など，興味深い結果が得ら れている.

河口域の密度成層場における, 河川から供給された懸 濁粒子の挙動については, 数值シミュレーションにより 検討した例もみられる2. しかし，河口港湾においては， 浚渫により水深が急変するなど, 人工的な地形条件にお ける密度成層の形成と, それに伴う懸濁物挙動一の影響 については未解明である。 また, 懸濁物中の泥粒子の濃 度増大により, 密度流的な振る舞いを示すFluid mud輸送 が, 出水時等の擾乱時における河口域周辺での泥の輸送 形態の一つとして重要となる34). それらによる航路埋没 現象とその対策に関寸る検討例》もみられるものの, 塩 分躍層が形成される中でのFluid mud輸送の実態や, 河口 港湾での埋没要因として検討した例はみられない.

本論文では，前報にて示した現地観測結果のうち，出 水期間における河口港湾内での密度躍層や䀣濁物濃度の 空間分布に注目し，その際に生じた土砂輸送過程につい 
て整理する.さらに，浚渫域最上流側の水深急変部での 流下土砂の挙動の把握を目的とした，淡水・海水による 密度躍層を考慮した水槽実験を実施したので，その結果 について報告する。

\section{2. 河口港内での現地観測結果}

観測対象とした新潟港西港地区は，信濃川河口に位置 し（図-1），定期フェリー航路の主要な交流拠点となっ ている. 同港内では水域ごとに定められた航路・泊地の 水深 $(5.5 \mathrm{~m} \sim 12 \mathrm{~m})$ を維持するため, 年間約 80 万 $\mathrm{m}^{3}$ の浚 渫が定期的に行われている. 図-1には濁度等の水質観測 点の位置と水深を示している.

国土交通省水文・水質データベースから，帝石橋観測 所（関屋分水路河口より $3.1 \mathrm{~km}$ 地点）における河川流量 データを取得し, 本研究で底質・水質調查を実施した時 期を含む 2012 年および 2013 年の時系列データを示した ものが図-2である，調査を実施した各時期（図中の矢印 (1) (3)）における河川流量についてみると, 最も流量の 多かった時期(3)（2013年7月下旬 8月上旬）には，日平 均流量が $1,000 \mathrm{~m}^{3} / \mathrm{s}$ 超えていた，それ以外の調查時期(1)

（2012 年 1 月）および(2)（2012 年 11 月）では, $400 \sim 600 \mathrm{~m}^{3} / \mathrm{s}$ 程度の流量となっている. ただし, 関屋分水 路とその分岐点にある新潟大堰および信濃川水門により， 港内に流入する河川流量は制御されており，同水門での 配分ルールによれば，上記の出水時（時期(3)）において も港内側には約 $450 \mathrm{~m}^{3} / \mathrm{s}$ ，それ以外の時期（時期(1)，(2) には $380 \mathrm{~m}^{3} / \mathrm{s}$ 程度となる.

図-1に示寸航路縦断方向に設けた Stn.A から D の各観 測点で測定された塩分と SS 濃度の鉛直分布について, 各地点ごとにそれぞれの観測時期の結果を重ねて示した ものが図-3 および図-4 である. なお各データの計測日 は，(1)2012年 1 月 12 日・13日，(2) 2012年 11 月 22 日， (3) 2013年 7月 31 日である. Stn.Bについては時期(3)の出 水時の夕計測を行っている. 図中に示した横破線は，時 期(3)における Stn.A（非浚渫域）の調査時の水深であり, 下流側観測点の蹋層の水深と対比できるようにした.

塩分分布の特徴として, 浚渫による水深急変部の下流 側となる Stn.Cでは，上流側（非浚渫域）水深にほぼ相 当する水深層で明瞭な塩分躍層が形成されている. さら に下流側の Stn.D においては, 上流側水深よりも上層で 淡水と海水の混合が生じていることが確認できる，一方， SS 濃度の鉛直分布においても，下流側では明瞭な濃度 躍層がみられ, 淡水層に相当する水深にて SS 濃度が高 く, 海水層で急激に減少しており，流下してきた懸濁物 は主に上層の淡水層で外海に向かって輸送されている. さらに, 前報 (中川ら )) で示したように, Stn.Cの下層 においては，湿潤密度が約 $1,100 〜 1,200 \mathrm{~kg} / \mathrm{m}$ の範囲にあ

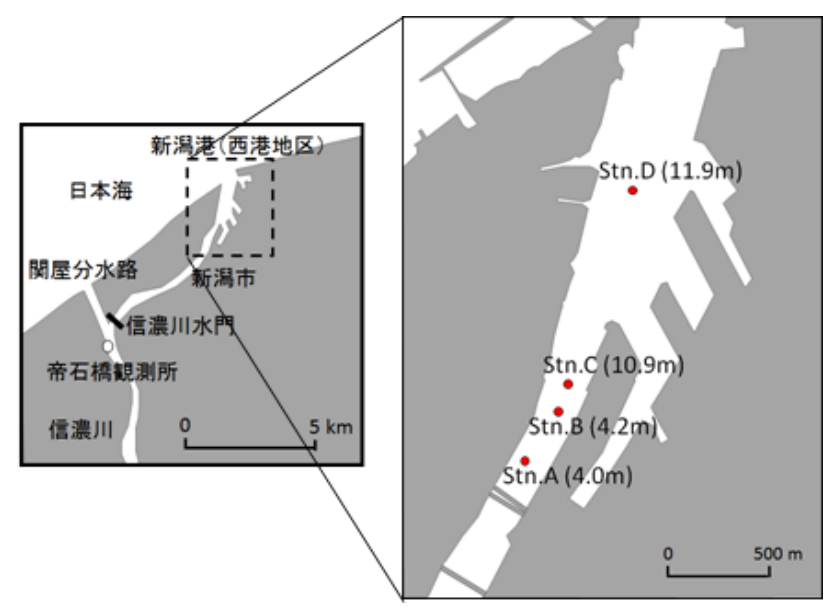

図-1 調查対象水域（新潟港（西港地区）の位置と 港内調查点の位置. カッコ内は調查時の水深. )

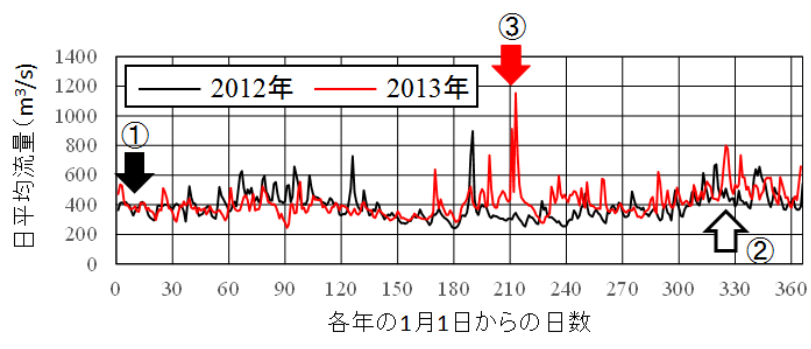

図-2 帝石橋観測所における河川流量と調查実施時期

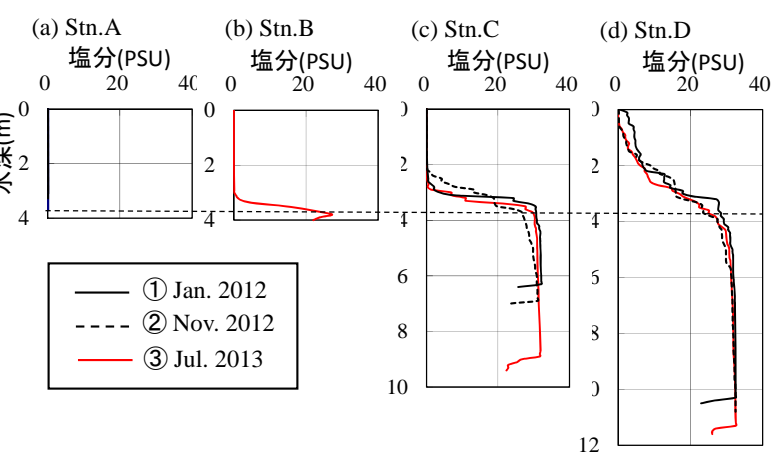

図-3 港内縦断方向にみた塩分の鉛直分布の変化 ((a)Stn.Aの塩分はいずれの観測時も 0psu)

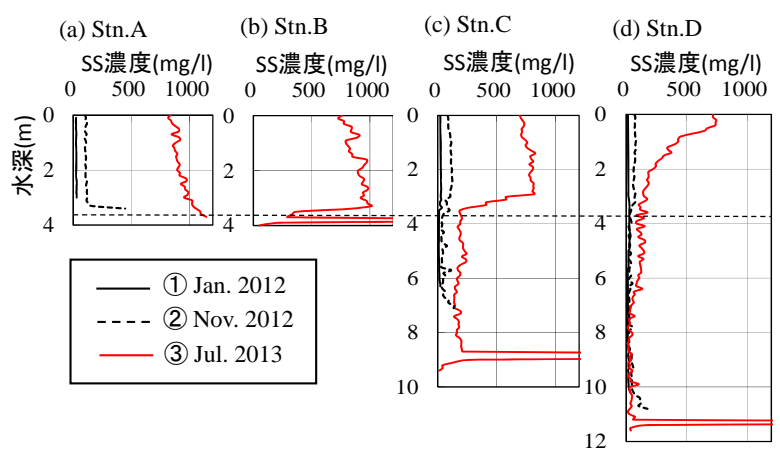

図-4 港内縦断方向にみた SS 濃度の鉛直分布の変化

る濁水の集積が 30cm 程度の厚さで生じていることが確 認されており，いわゆる Fluidmud輸送による浚渫域への 泥土の侵入が示唆されている. 


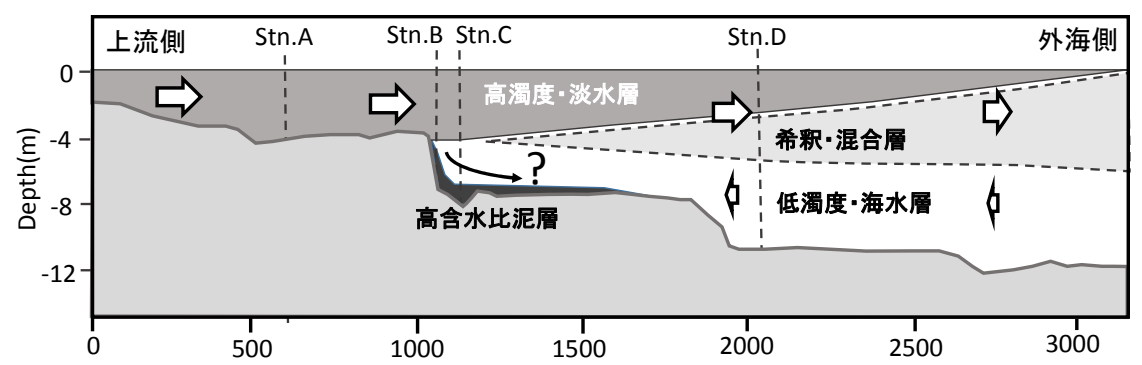

図-5 出水時の河口港内における流下土砂の空間分布模式図

上記の水質等の観測結果をふまえ，当該水域で実測さ れた地形縦断分布の上に，流下土砂の輸送過程を模式的 に示したものが図-5 となる.このような状況が形成さ れる要因として, 日本海側では潮汐振幅が小さいため, 淡水と海水の混合が小さい（弱混合）条件にあることや, 出水時の塩水くさびの遡上端が浚渫域上流端（Stn.B 付 近）となることに起因する.上流側での流量制御や浚渫 による地形制御の結果として，このような水理・地形的 条件が創出されていることも重要な点である.

一方，海水と接することによる懸濁粒子の凝集（フロ ッキュレーション) などの化学的作用も, 河口域での土 砂輸送を評価寸る上では重要な因子であるけれども，本 研究では, 密度成層場における懸濁粒子の移流拡散と, 特にFluidmudの深部への重力流的移動に注目し，物理的 挙動の把握を目的とした以下の水槽実験を行った.

\section{3. 水槽実験による流下土砂挙動の把握}

\section{(1) 実験方法}

実験は港湾空港技術研究所の海底流動実験水槽（図-6) を用いて行った．水槽上段の水路部（幅80cm）におい て，上下流両端の床面よりも梁さ40cmの掘り下げられ た試験区間の一部に，図-7に示すような河口港湾での水 深急変部を想定した模型地形を作成した．掘り下げ部分

（図-7中に下層と表示）に，まず久里浜湾より汲み上げ た海水を充填したのちに，水槽内全体に淡水（水道水） を満たすことにより，水槽上段の試験区間に淡水・海水 の密度踓層を再現した. 水槽内の淡水部分は, プロペラ 式の還流装置により水流を発生させることができ, 試験 区間の深掘り部に充填された海水層の直上に淡水を流下 させることで，現地河口港湾でみられた水理環境（図-5） の再現を試みた.

一方，濁水の流下に関しては，カオリナイト粘土粉末 を水道水で濃度調整した濁水を, 水深急変部の頂部に設 置したアクリルパイプ製のノズルから投入した．流量調 節バルブにより，毎分約 0.9 リットルの濁水を流れを発 生させている水槽中に約10分間投入した（図-8）.

濁水の流入条件に関しては, 出水時の上流側での流下 土砂の濃度分布の観測結果（図-4(a)）をみると，底層か

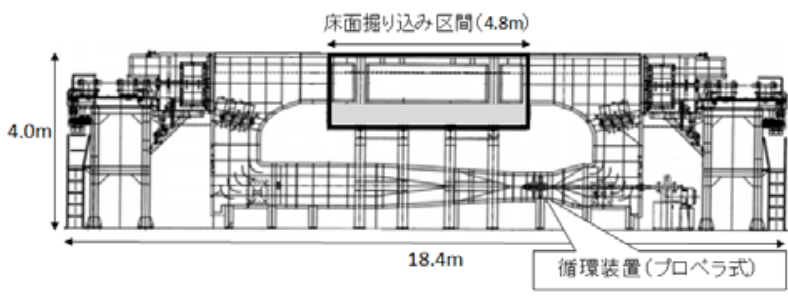

図-6 実験に用いた循環水槽の全体図（水槽上段の 床面掘り込み区間内に図-7に示寸試験区間を設置)

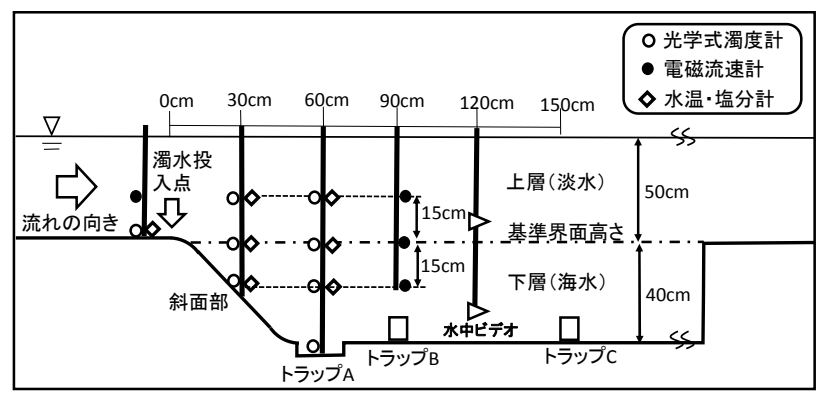

図-7 実験水槽内における水深急変部地形と淡水・海 水による密度躍層の再現と計測器の固定設置位置

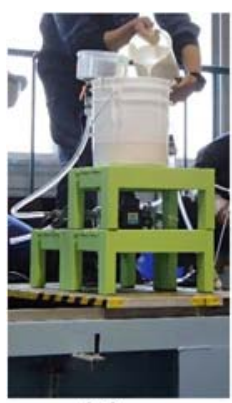

(a)

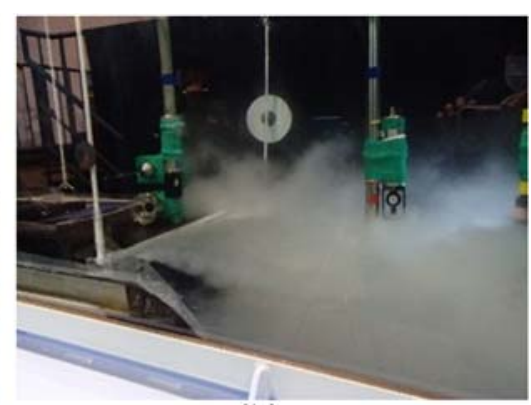

(b)
図-8 濁水タンク (a) と水槽内への投入の様子(b)

ら水表面まで高濃度な濁水が流下しており，現地の状況 とは異なる. 本実験では水深急変部でのFluid mudの重力 流的な底面床上の移流の可能性を検討寸るため, 底面直 上の濁水のみに注目したことになる.

濁水投入実験における計測項目としては，投げ込み式 の多項目水質計（JFEアドバンテック・AAQ1183）によ る塩分や濁度の鉛直分布測定のほか, 図-7に示寸ように 各地点に電磁流速計や光学式濁度計を固定することによ り，流速場と濁質の濃度場の時系列変動の把握を試みた。 
なお，すべての濁度計の計測結果は，実験に用いたカオ リナイト粘土粉末による濁水を用いたキャリブレーショ ンにより, SS濃度（mgl）に換算された数值をここでは 示す. また，水中ビデオ撮影により，濁水の拡散状況や Fluid mudの動態を捉える動画データの取得も行った.

\section{(2) 実験ケース}

流動の条件として，上流境界部の測定点（図-7）にお ける底面床上 $15 \mathrm{~cm}$ での水平流速が約 $13 \mathrm{~cm} / \mathrm{s}$ および約 26cm/s となる2ケースを設定した. 各流速条件でのフル 一ド数はそれぞれFr1 $=0.059, \mathrm{Fr} 2=0.118$ となり，実スケー ルでの上流側水深を $4 \mathrm{~m}$ と仮定すると, 相当するフルー ド数では約37 74cm/sの流れを対象としていることにな る. 一方，投入濁水の濃度については100,000mg/および 200,000mg/の2ケースを行ったところ，100,000mg/の結果 においてはFluid mudとしての流動機構は観察されなかっ たことから，ここでは200,000mg/のケースのみ示すこと とする. また, 密度成層の有無による浮遊懸濁物の輸送 への影響を評価するため, 水槽内をすべて淡水で満たし て, 流速条件および濁水投入条件を同一とした実験も比 較のために実施している，これらの条件設定の一覧を表 -1に示寸.

流速および密度場の条件により, 投入濁度の輸送過 程に影響を及ぼすことが考えられる，そこで，試験区間 における流れ場の情報として, 濁度投入点から $90 \mathrm{~cm}$ 下 流側の深掘り部内（図-7）の密度界面を挟む鉛直3点で, 電磁流速計により計測（測定間隔1 $\mathrm{Hz}$ ，約10分間測定） された主流方向の平均流速と変動流速（ここでは標準偏 差として算定）を表-2に各ケースごとに示寸.

変動流速の大きさは，浮遊懸濁物の鉛直混合を支配 する乱れ強度に関係する，表-2を見ると，密度躍層が無 い各ケース（CaseB-1およびB-2）の方が，密度成層あり

表-1＼cjkstart実験ケース一覧

\begin{tabular}{c|c|c|c}
\hline ケース名 & 密度条件 & 上流境界の流速 & 濁水濃度 \\
\hline CaseA-1 & \multirow{2}{*}{ 成層あり } & $13.5 \mathrm{~cm} / \mathrm{s}$ & \multirow{3}{*}{20,000} \\
\cline { 1 - 1 } CaseA-2 & & $26.7 \mathrm{~cm} / \mathrm{s}$ & \multirow{2}{*}{$\begin{array}{c}\text { 200 } \\
\text { CaseB-1 }\end{array}$} \\
\cline { 1 - 1 } 淡水のみ & $12.9 \mathrm{~cm} / \mathrm{s}$ & \\
\cline { 1 - 1 } CaseB-2 & & $26.4 \mathrm{~cm} / \mathrm{s}$ & \\
\hline
\end{tabular}

表-2 試験区間での主流方向の平均流速（上段）と変動 流速（下段カッコ内）単位: $\mathrm{cm} / \mathrm{s}$

\begin{tabular}{c|c|c|c|c}
\hline 計測位置 & CaseA-1 & CaseA-2 & CaseB-1 & CaseB-2 \\
\hline 基準界面 & 12.9 & 21.8 & 12.0 & 28.0 \\
$+15 \mathrm{~cm}$ & $(0.24)$ & $(2.01)$ & $(2.13)$ & $(3.31)$ \\
\hline 基準界面 & 6.77 & 14.9 & 4.98 & 5.89 \\
$\pm 0 \mathrm{~cm}$ & $(1.89)$ & $(1.80)$ & $(2.82)$ & $(5.39)$ \\
\hline 基準界面 & -0.55 & 1.18 & 1.58 & -2.63 \\
$-15 \mathrm{~cm}$ & $(0.24)$ & $(2.01)$ & $\mathbf{( 2 . 1 9 )}$ & $(2.53)$ \\
\hline
\end{tabular}

(a) Case A-1

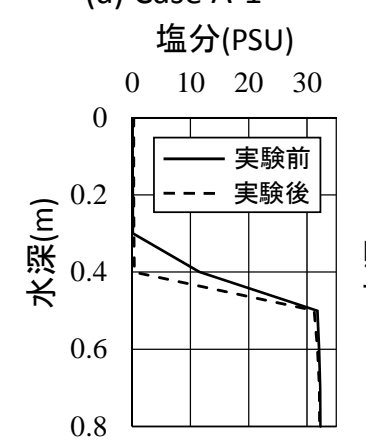

(b) Case A-2

塩分(PSU)

$\begin{array}{llll}0 & 10 & 20 & 30\end{array}$

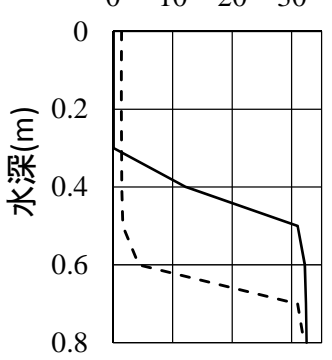

図-9 濁水投入点から下流 $90 \mathrm{~cm}$ 地点での塩分の鉛直 分布

の各ケース (CaseA-1およびA-2) に比べて, 相対的に変 動流速が大きく, 特に基準界面（密度成層がある場合の 初期界面高さ）で，せん断流による乱れが顕著である.

密度成層の再現状況としては，図-9に試験区間内（濁 水投入点より $90 \mathrm{~cm}$ 地点）にて多項目水質計の昇降によ り測定した塩分の鉛直分布を示す，同図には，Case A-1 およびCase A-2のそれぞれについて，実験前（実線）お よび実験後（破線）の結果を示す．実験前はいずれも水 深30 50cmの間に明確な塩分躍層が形成されていること がわかる．また約10分間，流れをかけ続けた実験後にお いても塩分躍層は消滅することはないものの, 流れの条 件に依存してその界面高さには変化が生じている.

\section{(3) 実験結果と考察}

試験区間下流域（掘り下げ部）での，懸濁物濃度の 空間分布の特徵を把握するため, 濁水投入点より下流側 60cm地点（図-7）の基準界面を挟む鉛直3層ならびに床 面（掃流状態で流下寸る濁水の把捉を目的に設けられた， 斜面最下部のトラップ内）に固定設置された光学式濁度 計の測定結果を示す.

斜面部でのFluid mud輸送（密度流的な濁質の斜面床 上の流下）が水中ビデオ画像により確認されたCaseA-1 の結果を図-10に示す．基準界面付近のSS濃度の変化を みると, 濁水投入から2分間程度は基準界面の高さのみ にSS濃度の上昇がみられ, その後, 基準界面の下層 $15 \mathrm{~cm}$ において濃度の上昇が確認できる. 基準界面より も上層では，濁水投入 (約10分間) の全期間においてほ とんどSS濃度の上昇が生じていない. 一方，当該地点 の底面に相当する斜面最下部に設けたトラップ部のSS 濃度の変化 $($ 図-10(b)）を見ると, 濁水投入から1分以内 に急激な濃度上昇が確認でき，その濃度は上述の水中部 分よりも高濃度であり計測器の測定範囲上限にまで達し ている. 寸なわち, 斜面床部に沿って密度流的に流下し た高濁度水塊が最下部のトラップ部に侵入したことを意 味し，その様子はビデオ画像でも確認されている，。 


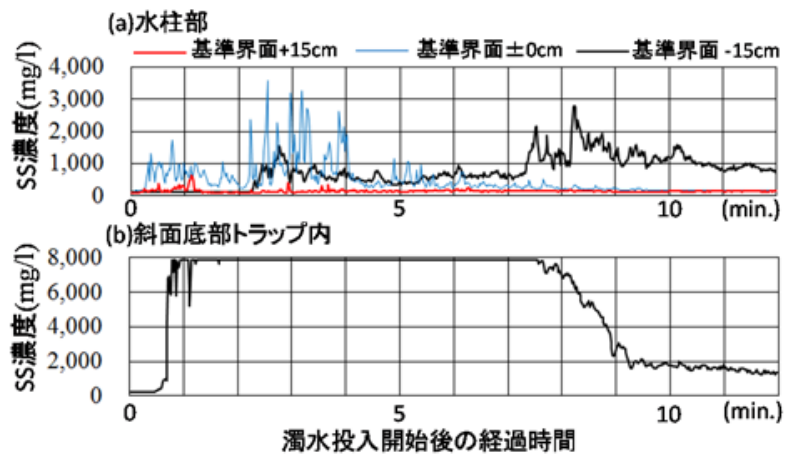

図-10 試験区間の SS 濃度の時系列変化（Case A-1）

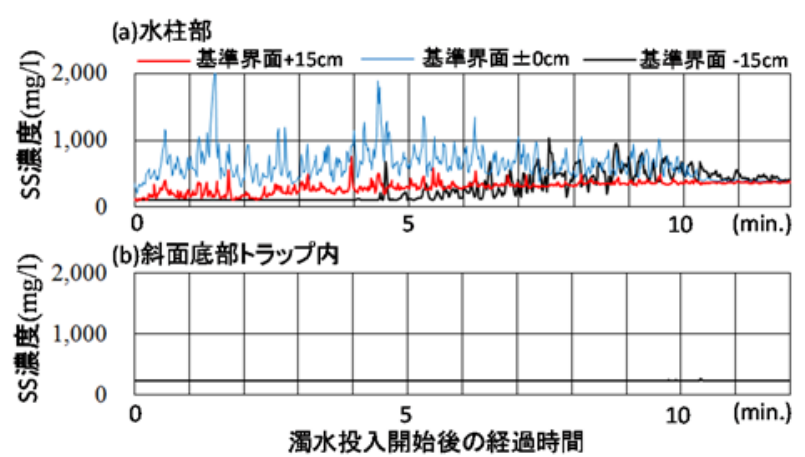

図-11 試験区間の SS 濃度の時系列変化（Case A-2）

これに対し, Case A-1に比べて上流からの流れが速く 乱れの程度も強くなる（表-2）Case A-2の場合には，斜 面最下部のトラップ内のSS濃度の上昇はほとんど見ら れず（図-11(b)），むしろ基準界面やそれよりも上層で のSS濃度の上昇が生じている（図-11(a)）。ビデオ画像 からも，Case A-1で生じていたようなFluid mud輸送は見 られず，下層の海水層内では透明度が高い状態が維持さ れていることが確認されている. 寸なわち，本ケースに おいては，投入後の濁水は一様流の乱れによる拡散によ り希釈され，重力流的な斜面流下が生じる前に，上層の 淡水層を浮遊状態で流下したことになる.

Case A-1およびA-2の各ケースにおける，濁水投入停止 後に濁水投入点より下流 $90 \mathrm{~cm}$ 地点で測定されたSS濃度 の鉛直分布を図-12にそれぞれ示す．Case A-1においては 上述のとおり，斜面部を流下した高濃度濁水の影響によ り, 特に底面付近に高濃度な濁水の集積が生じているの に対し，Case A-2においては鉛直混合によりほぼ一様化 したSS濃度が上層部にみられ，60cmより下層ではSS濃 度は急激に低下している. Case A-2にみられる下層の低 濃度層の水深帯は，同時に計測された塩分濃度の鉛直分 布の結果（図-9(b)）と照らし合わせると，塩分躍層の下 層（海水層）の水深帯とほぼ一致している.これは，現 地観測でも確認されているように，上流からの浮遊㲘濁 物が上層の淡水層を流下し, 下層の海水層は低濃度な状 態が保持される状況（図-5）を再現したものとなる.

一方，密度躍層の有無による懸濁物輸送過程への影響

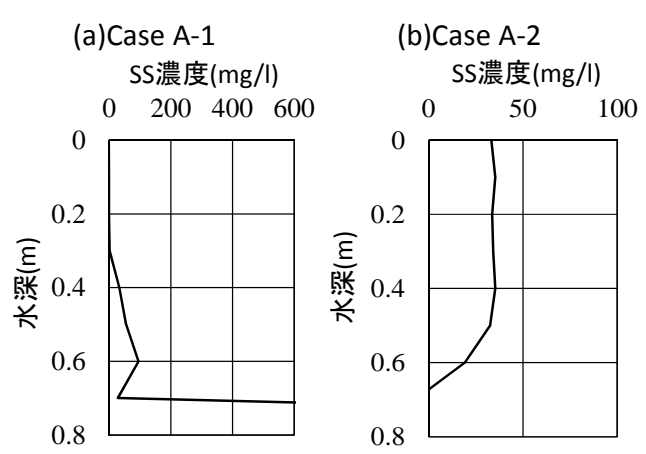

図-12 濁水投入点から下流 $90 \mathrm{~cm}$ 地点で測定された

SS 濃度鉛直分布（密度成層ありの各ケース）

を確認するため，Case B-1およびCase B-2の同様な測定デ 一タの結果を図-13および図-14に示寸． Fluid mud輸送が 確認されたCase A-1と流動条件が同じであるCase B-1の結 果についてみると, 斜面最下部のトラップ内のSS濃度 の上昇（図-13(b)）がCase A-1のときと同様にみられる. しかしながら，その濃度の上昇速度はCase A-1に比べる と緩やかであることや，同地点の水中部のSS濃度（図13(a)）をみると基準界面だけでなく基準界面の下層にお いて, 濁水投入直後からSS濃度の上昇が生じている. これは，Case A-1では基準界面下層での濃度上昇がほと んど生じることなく，その直下の斜面最下部でFluid mud の侵入による急激な濃度上昇が生じたことと, Case B-1 では懸濁物の輸送経路が異なることを意味する.この点 について水中ビデオ動画で確認すると, 濁水投入点の下

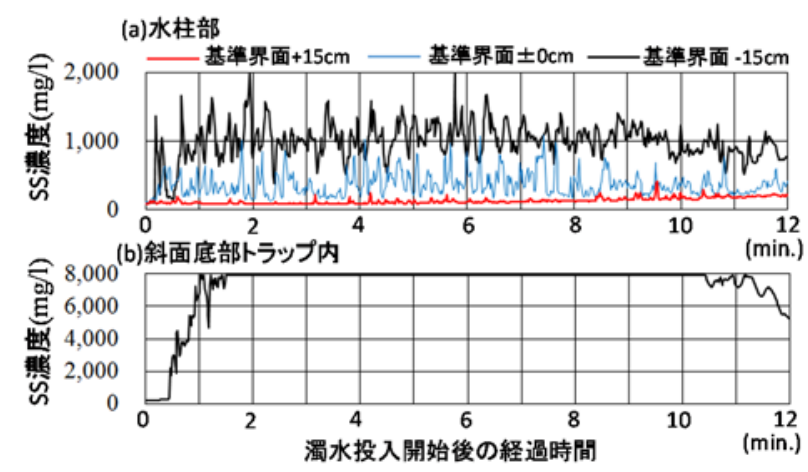

図-13 試験区間の SS 濃度の時系列変化（Case B-1）

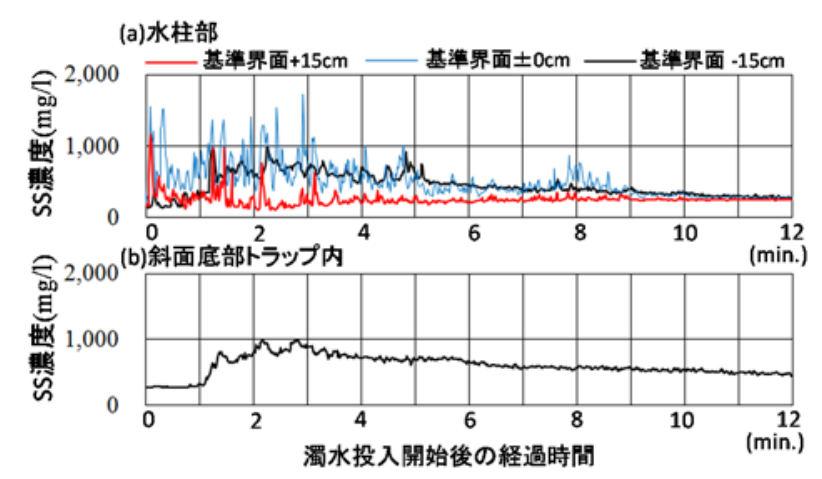

図-14 試験区間の SS 濃度の時系列変化（Case B-2） 
流側では，流れによる濁質の移流と拡散・沈降により下 層のSS濃度が上昇していく様子がみてとれる.さらに, 海水層への懸濁物沈降の抑制がみられたCase A-2に対し て，同じ上流での流れと濁水の条件であるCase B-2では, 下流域で乱れが最も大きく（表-2）密度躍層も存在しな いことから，鉛直方向のいずれの層においてもSS濃度 が上昇し（図-14），SS濃度の鉛直方向の一様化（図15(b)）が確認できる.

\section{4. おわりに}

出水時の河口港における塩分やSS濃度等の空間分布 や地形条件の特徽をふまえ, 海水と淡水による密度界面 を考慮した懸濁物の輸送過程の解明を目的とした水槽実 験を行った。 その結果, 高濃度濁水が水深急変部の斜面 を重力流として流下するFluid mud輸送の再現に成功した. また同じ濃度の濁水を投入しても，上流からの流れ（乱 れ）の条件に応じて, 投入濁水の濃度希勫が生じるため, Fluid mud的な輸送は発生しなくなることを示した.さら に上層の淡水層により輸送される懸濁物は, 塩分躍層の 存在により, 下層（海水層）への拡散・沈降が抑制され ることを, 躍層が無い場合の実験との対比により明らか とした.

なお，本実験では上流端にて強制的に高濁度水を投入 することにより, Fluid mud輸送の再現を試みているもの の, 現地でのこのような生成過程は未解明である. 実験 でみられた乱れによる希䣋効果も含め, 河口港湾の浚渫 域上流端での土砂輸送機構の解明が，下流側の埋没対策 の効率化にも結び付く可能性を有することから, 今後も 現地データの取得も試みつつ, 河口土砂動態の定量的 な評価手法の精度向上を推進する予定である.

謝辞 : 本調査をす寸めるにあたり，国土交通省北陸地方 整備局新潟港湾・空港整備事務所（松本祐二所長 (当時)) の主催による埋没土砂技術検討会を通じて, 中村由行横
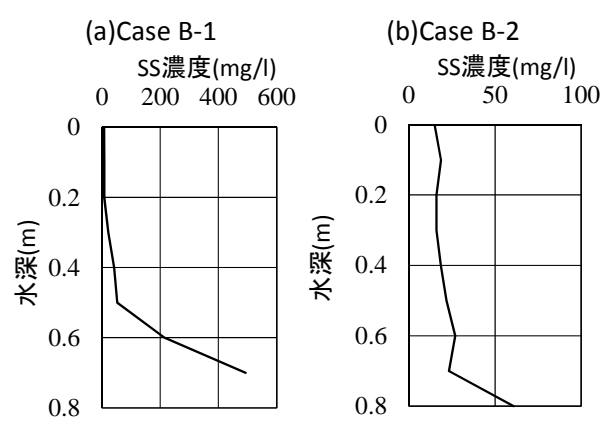

図-15 実駼終了時に濁水投入点加ら下流 $90 \mathrm{~cm}$ 地点 でのSS 濃度鉛直分布（密度成層なしのケース）

浜国立大学教授, 菊池喜昭東京理科大学教授, 細山田得 三長岡技術科学大学教授の各委員より貴重な意見を頂い た. また水槽実験の実施においては日本ミクニヤ(株)お よび(株)コンクリー診断也夕ーの各社の協力を得た。

\section{参考文献}

1) 中川康之, 篠澤巧, 高嶋紀子, 渡邊理之, 清水雄太: 河口港における底泥堆積特性の把握に関する現地調 查, 土木学会論文集 B2（海岸工学）, Vo.71, No.2, I_571-I.576, 2015.

2) 柳哲夫, 磯部篤彦, 河口域での㲘濁粒子の挙動に関 寸る数值実験, 沿岸海洋研究ノート, 第 25 巻, 第 1 号, pp.61-66, 1987.

3) Fan, S., D.J.P. Swift, P. Traykovski, S. Bentley, J. C. Borgeld, C. W. Reed and A. W. Niedoroda: River flooding, storm resuspension, and event stratigraphy on the northern California shelf: observations compared with simulations, Marine Geology, Vol.210, pp.17-41, 2004.

4) 中川康之, 灘岡和夫, 八木宏, 二瓶泰雄, 木村彰宏, 久保田踊児, 吉田行秀, 東京湾羽田沖における泥質 物の堆積分布特性を考慮した底泥輸送モデルの構築, 土木学会論文集 B2（海岸工学）, Vo.69, No.2, I_571-I.575, 2013.

5) Rahman Hidayat, 入江功, 森本剣太郎, 小野信幸: アジア地域の港湾におけるシルテーション対策とフ ルードマッド, 海岸工学論文集, 第 48 巻, pp.14061410. 2001.

(2016.3.16 受付)

\section{DISCHARGED MUDDY SEDIMENTS AND THEIR DEPOSITION PROCESS AROUND PORT FACILITY AT RIVER MOUTH}

\section{Yasuyuki NAKAGAWA, Noriko TAKASHIMA, Kazuo MURAKAMI, Yoshio GOTOH and Ippei NAGAI}

The aim of the research is to elucidate suspended sediment transport and their deposition processes especially at river mouth or estuarine area. Several specific features of sedimentary processes during a flood condition have been observed in the field around the Port of Niigata at the mouth of the Shinano river, showing dispersal of highely turbid water in the near surface fresh water layer and formation of fluid mud layer near the bottom at the same time. The hydraulic model experiments were also carried out with a circulating flume to elucidate the fluid mud transport on the steep slope modeling the edge of navigation channel. The experiments also clarified the influence of the halocline on the suspended sediment transport process at river mouth area. 